\title{
18. Eleştirel dinleme becerisinin kapsamının incelenmesi ${ }^{1}$
}

\section{Nahide İrem AZİZOĞLU²}

\section{Alpaslan OKUR3} APA: Azizoğlu, N. İ.; Okur, A. (2021). Eleştirel dinleme becerisinin kapsamının incelenmesi.
RumeliDE Dil ve Edebiyat Araştırmaları Dergisi, (22), 327-337. DOI: 10.2900o/rumelide.898553.

\section{$\ddot{O} \mathbf{z}$}

Günümüz toplumunda bireyler aynı anda birden fazla kaynaktan dinleme unsurlarına maruz kalmaktadır. Bu nedenle dinlenilen bilgilerin gerekli olanlarının seçme ve değerlendirme yapabilme önemli beceriler haline gelmiştir. Dinlediklerini tam olarak kavrayabilme ve değerlendirmeler yapma eleştirel dinleme becerisini ön plana çıkaran kavramlardır. Eleştirel dinleme ilk olarak 1940lı yıllarda II. Dünya Savaşı döneminde öne çıkan bir beceri olsa da günümüzde halen güncelliğini korumaktadır. Eleştirel dinleme becerisinin 2006 Türkçe Öğretim Programı’ndan itibaren programlarda bir dinleme/izleme yöntem/tekniği olarak yer aldığı bilinmektedir. Buna rağmen literatürde eleştirel dinlemenin kapsamının tam olarak belirlenmediği görülmektedir. Bu nedenle araştırmada eleştirel dinlemenin kapsamının belirlenmesi amaçlanmaktadır. Bu amaca yönelik olarak literatürde eleştirel dinleme becerisine ilişkin yapılan araştırmalar incelenmiştir. Çalışmada betimsel tarama yöntemi kullanılarak 1946-2018 yılları arasında yapılan eleştirel dinleme becerisinin kapsamından bahsedilen on dört araştırma incelenmiştir. Alanda kabul görmüş bir sınıflama olmamasından dolayı literatürdeki bilgilerden hareketle yeni bir eleştirel dinleme sınıflaması ortaya çıkarılmıştır. Bu sınıflama hazırlanırken literatürdeki sınıflamalar incelenmiş ve ortak olanlar bir boyut altında birleştirilmiştir. Araştırmada eleştirel dinlemeye ilişkin sınıflama ilk olarak araştırmacılar tarafından hazırlanmış ve üç Türkçe eğitimi alan uzmanından görüşler alınarak sınıflama yeniden düzenlenmiştir. Yapılan değerlendirmeler sonucunda eleştirel dinlemenin metindeki öznel/nesnel ifadeleri belirleme, metnin anlatımının taraflı olup olmadığını belirleme, metnin konusunu belirleme, metnin ana fikrini belirleme, metindeki propaganda unsurlarını belirleme, metnin konusunu değerlendirme, metinden sonuç çıkarma, metindeki kanıtları ve konuşmacıyı değerlendirme, metindeki tutarlılığı değerlendirme becerilerini kapsadığı tespit edilmiştir. Buradan hareketle eleştirel dinleme becerisine ilişkin sinıflamalar incelendiğinde eleştirel dinlemenin farklı bileşenlerden oluşan bir bütün olduğunu sonucuna ulaşılmıştır.

Anahtar kelimeler: Dinleme, dinleme becerisi, eleştirel dinleme, eleştirel dinleme becerisi

$\mathrm{Bu}$ çalışma "Ortaokul öğrencilerinin eleştirel dinleme becerilerinin geliştirilmesi" başlıklı doktora tezinden hareketle hazırlanmıștır. XII. Uluslararası Dünya Dili Türkçe Sempozyumu'nda sunulan bildirinin genişletilmiș halidir.

Dr. Arş. Gör., Sakarya Üniversitesi, Eğitim Fakültesi, Türkçe ve Sosyal Bilimler Eğitimi Bölümü, Türkçe Eğitimi ABD (Sakarya, Türkiye), azizoglu@sakarya.edu.tr, ORCID ID: 0ooo-ooo3-2738-9856 [Araştırma makalesi, Makale kayıt tarihi: 04.12.2020-kabul tarihi: 07.02.2021; DOI: 10.29000/rumelide.898553]

3 Prof. Dr., Sakarya Üniversitesi, Eğitim Fakültesi, Türkçe ve Sosyal Bilimler Eğitimi Bölümü, Türkçe Eğitimi ABD (Sakarya, Türkiye), aokur@sakarya.edu.tr, ORCID ID: 0000-0002-2868-063X

Adres $\mid$ Address

RumeliDE Dil ve Edebiyat Araşttrmaları Dergisi $\quad$ RumeliDE Journal of Language and Literature Studies Osmanağa Mahallesi, Mürver Çiçeği Sokak, No:14/8 Osmanağa Mahallesi, Mürver Çiçeği Sokak, No:14/8

Kadıköy - İSTANBUL / TÜRKIYE 34714 Kadıköy - ISTANBUL / TURKEY 34714 e-posta: editor@rumelide.com e-mail: editor@rumelide.com,

tel: +90 505 7958124, +90 2167730616 phone: +90 505 7958124, +90 2167730616 


\title{
Examining the scope of critical listening skill
}

\begin{abstract}
In today's society, individuals are exposed to listening elements from more than one source at the same time. For this reason, choosing the required ones among the listened information and being able to make an evaluation have become important skills. Understanding exactly what is listened to and making evaluations are the concepts that emphasize critical listening skill. Although critical listening was a prominent skill initially in the 1940 o during World War II, it still remains up to date today. Critical listening skill is known to be included in the programs as a listening/watching method/technique as of the 2006 Turkish Teaching Curriculum. However, in the literature, it is seen that the scope of critical listening is not determined exactly. Therefore, this study aimed to determine the scope of critical listening. For this purpose, the studies conducted on critical listening skill in the literature were examined. In the study, using the descriptive survey model, fourteen studies, which were conducted in the scope of the critical listening skill between 1946-2018, were examined. Since there isn't any accepted classification in the literature, a new critical listening classification was created based on the information in the literature. While preparing this classification, the classifications in the literature were examined and the common ones were combined under one dimension. In the study, the classification related to critical listening was first prepared by the researcher, and the classification was rearranged by taking the opinions of three Turkish language education experts. As a result of the evaluations made, it was determined that critical listening included the skills of determining the subjective/objective expressions in the text, determining whether the narration of the text is biased, determining the subject of the text, determining the main idea of the text, determining the propaganda elements in the text, evaluating the subject of the text, making inferences from the text, evaluating the evidences and the narrator in the text, and evaluating the consistency in the text. Thus, when the classifications related to critical listening skill were examined, critical listening was concluded to be a whole consisting of different components.
\end{abstract}

Keywords: Listening, listening skill, critical listening, critical listening skill

\section{Giriş}

Dört temel dil becerisinden birisi olan dinleme becerisi ilk kazanılan beceri alanı olması ve diğer dil becerilerinin kazanılmasında temel oluşturmasından dolayı bireyin hayatında önemli bir yere sahiptir. Dinleme becerisinin anne karnında geliştiği, fetüsün dışarıdan gelen sesleri duyabildiği, dinlemenin bireyin sosyal ve iletişimsel becerilerinin temelini oluşturduğu bilinmektedir (Lundsteen, 1971: 16; Wolvin ve Coakley, 2000: 143). Dinlemenin ilk kazanılan dil becerisi olması bireyin ilk öğrenmelerinin dinleme becerisinin kullanılarak gerçekleştiğine işaret etmektedir (Güneş, 2013: 80). Bu durumdan hareketle bireyin ana dilini dinleme becerisini kullanarak kazandığı sonucuna ulaşılabilir (Mersand, 1951: 263).

Dinleme becerisi ilk kazanılan dil becerisi olmasının yanında bireyin günlük hayatta en sık kullandığı dil becerisidir. Farklı araştırmalarda (Rankin, 1928; Pinnell ve Jagar, 2003; Robertson, 2002) günlük hayatta yarıya yakın oranda dinleme becerisinin kullanıldığı açıklanmıştır. Bu durumu sadece bireylerin sosyal hayatları ile sınırlandırmak doğru olmayacaktır. Imhof (2008) ilkokul öğrencilerinin

\footnotetext{
Adres Address

RumeliDE Dil ve Edebiyat Araşttrmalar Dergisi $\quad$ RumeliDE Journal of Language and Literature Studies Osmanağa Mahallesi, Mürver Çiçeği Sokak, No:14/8 Osmanağa Mahallesi, Mürver Çiçeği Sokak, No:14/8 Kadıköy - İSTANBUL / TÜRKIYE 34714 Kadıköy - ISTANBUL / TURKEY 34714 e-posta: editor@rumelide.com e-mail: editor@rumelide.com, tel: +90 505 7958124, +90 2167730616 phone: +90 505 7958124, +90 2167730616
} 
okuldaki zamanlarının en az \%60’ını dinleyerek geçirdiklerini açlklamaktadır. Buradan hareketle dinlemenin hayatın her alanında bireyin ihtiyaç duyduğu bir beceri olduğu gerçeği ortaya çıkmaktadır.

Farklı kaynaklarda dinleme becerisine ilişkin yöntem, tür ve teknik sınıflamaları bulunmaktadır. Türkçe Öğretim Programlarında dinleme yöntem ve teknikleri katılımlı, katılımsız, seçici, yaratıcı, not alarak, empatik, eleştirel dinleme olarak açılanmaktadır. Eleştirel dinleme kavramı alanyazında genellikle bir dinleme türü, yöntemi ya da tekniği olarak geçmektedir. Eleştirel dinleme alanında yapılan araştırmaların tarihçesi incelendiğinde bu araştırmaların temelinin 1940'lı yıllara dayandı̆̆ı görülmektedir. Bu durumun nedeni II. Dünya Savaşı sırasında ABD yönetimi tarafından hem askerlere hem de halka eleştirel dinleme eğitimi verilmesinin planlanması olarak (Brewster, 1956: 10) açıklansa da eleştirel dinlemenin önemini sadece bu durumla sınırlandırmak mümkün değildir. Eleştirel dinleme II. Dünya Savaşı döneminin ihtiyaçlarından ortaya çıksa da bu kavram günlük hayatımızla yakından ilişkilidir. İletişimin temeli kaynağın gönderdiği mesajın alıcı tarafından tam olarak kavranmasına dayanmaktadır. Günümüzde kaynak kavramı sadece insanları ifade etmemektedir. Teknolojinin gelişmesi ile birlikte pek çok medya ve teknoloji aracından bilgi akışına maruz kalan alıcının mesajın içeriğini anlayabilmesi gerekmektedir. Farklı kaynaklardan aktarılan mesajın kavranmasının yolu eleştirel dinleyebilmekten kısacası mesajın içeriğini anlama, sorgulama ve değerlendirmekten geçmektedir.

Eleştirel dinlemenin bireyin dinlediklerini tam olarak anlaması, sorgulaması ile birlikte değerlendirme sürecini kapsayan bir beceri olduğu söylenebilir. Eleştiri kelimesinin kapsamında anlama ve değerlendirme kavramları yer aldığından eleştirel dinlemenin dinlediğini anlamaya ve değerlendirmeye dayandığı belirtilmelidir. Özellikle değerlendirme yapma becerisi üst düzey bir beceri olarak açıklandığından eleştirel dinleme ileri düzey dinleme olarak ifade edilebilir (Trace, 2013: 68). Eleştirel dinleme ile ilişkili olan beceriler incelendiğinde eleştirel dinlemenin dinleme becerisi (Doğan, 2017; Laurent, 1963) ve eleştirel düşünme becerisi (Lunsteen, 1963) ile ilişkili olduğu tespit edilmiştir.

Eleştirel dinlemenin kapsamına ilişkin yapılan araştırmalarda farklı sonuçlar belirtilmiştir. Bu konuda yapılan ilk çalışmalardan birinde (Beery, 1946) konuşmacının anlatımının taraflı olup olmadığını belirleme, verilen bilgilerin kaynağını sorgulama, konuşmacının tezini destekleyen kanıtları inceleme, konuyu farklı bakış açları ile değerlendirme, duygu belirten ifadeleri fark etme becerileri eleştirel dinleme kapsamında belirtilmiştir. Bu sınıflamada eleştirel dinlemenin fark etme, sorgulama ve değerlendirme basamakları üzerinde durulduğu görülmektedir.

Early (1954) eleştirel dinlemenin kapsamındaki becerileri gerçek ve görüş farkını belirleme, anlatımdaki duygu ifadelerini belirleme, anlatımdaki yanlı ifadeleri ve önyargıları belirleme, konuşmacının tezini değerlendirme, propaganda ifadelerini belirleme, konuşmadan hareketle çıkarımlar yapma ve konuşmayı değerlendirme, konuşmada yanlış anlaşılan kısımları belirleme, konuşmadaki pazarlama tekniklerini belirleme olarak tespit etmiştir. Bu sınıflamada eleştirel dinlemenin değerlendirme ve anlatımın tarafsızlığı boyutları üzerinde durulurken konuşmada propaganda ifadelerinin tespiti de vurgulanmıştır.

Devine (1961) çalışmasında eleştirel dinlemenin kapsamını konuşmadaki yönlendirmeleri fark etme, konuşmacının konuya hâkimiyetini inceleme, gerçek ve düşünce farkını tespit etme, konuşmacının amacını belirleme, konuşmadaki duygu belirten ifadeleri belirleme olarak açıklamıştır. Önceki sınıflamalardan farklı olarak burada konuşmacıyı değerlendirme ve konuşmanın amacının

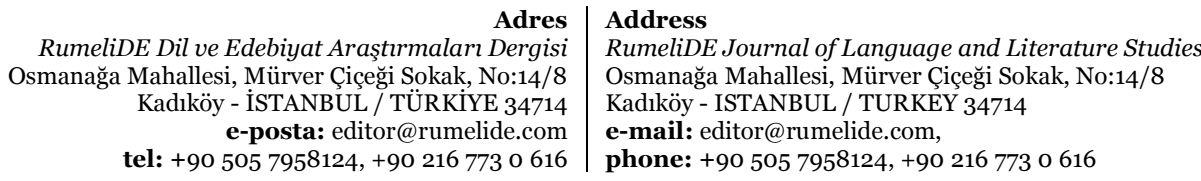


belirlenmesi boyutlarının olması dikkat çekicidir. Bunun yanında diğer sınıflamalarda olduğu gibi değerlendirme basamağında becerilere yer verilmiştir.

Lundsteen (1963) araştırmasında eleştirel dinlemede konuşmacının amacını belirleme, konuşmadaki propaganda ifadelerini analiz edebilme, konuyu değerlendirmenin ön planda olduğundan bahsetmektedir. Bu sinıflamada dinlenilenlerin tam olarak kavranmasının ve değerlendirilmesinin yanında konuşmadaki aldatıcı dil kullanımlarının analizine yer verilmiştir. Laurent (1963) konuşmada kullanılan duygu belirten ifadeleri tespit etmeyi, gerçek ve düşünce ifadelerini ayırt edebilmeyi, konuyu tam olarak kavramayı ve dinlenilenlerden hareketle sonuç çıarmayı eleştirel dinleme kapsamında ele almaktadır. Bu sınıflamada Lundsteen (1963) tarafından yapılan sinıflamada olduğu gibi dinlenilenlerin tam olarak anlaşılmasına ve konuşmacının kullandığı anlatımdaki aldatıcı dil unsurlarını belirlemeye odaklanılmıştır.

Groom (1970) eleştirel dinlemenin gerçek ile düşünce farkını belirleme, anlatımdaki duygu belirten ifadeleri belirleme, propaganda ifadelerini tanıma, konuşmadan çıkarımlar yapabilme, konuşmacının amacını sorgulama becerilerini kapsadığını ifade etmektedir. Bu sınıflamada eleştirel dinlemenin birden fazla yönü üzerinde durulduğu ve daha geniş kapsamlı bir açıklama yapıldığı görülmektedir. Richards (1977) konuşmadaki varsayımları belirleme ve sonuç çıkarabilme, konuşmanın ana fikrini belirleme, konuşmadaki taraflı ifadeleri belirleme ve varsa yönlendirmeleri tespit etme, konuşmanın tutarlılı̆̆ını değerlendirme, öznel ifadelere dikkat etme, anlatımdaki mantıksal hataları sorgulama becerilerini eleştirel dinleme kapsamında değerlendirmektedir. Bu sınıflamada eleştirel dinlemeye ilişkin birçok değişken ele alınmış ve önceki sınıflamalardan farklı olarak anlatımın tutarlı olup olmadığının değerlendirilmesinden ve mantıksal hataların belirlenmesinden bahsedilmiştir. $\mathrm{Bu}$ nedenle önceki sınıflara göre daha farklı ve geniş kapsamlı bir değerlendirme yapıldığı söylenebilir.

Davis-Rice (1982) konuşmacının amacını belirleme, anlatımdaki öznel ifadelere dikkat etme, anlatımdaki gerçek ve düşünce farkını ayırt etme, konuya ilişkin sunulan kanıtları inceleme, konuya ilişkin sunulan kaynakları inceleme, konuya ilişkin bilgi edindikten sonra değerlendirme yapma, konuşmadan hareketle sonuç çıkarma, sunulan bilgileri alanyazın açısından değerlendirme becerilerinin eleştirel dinleme kapsamında yer alması gerektiğinden bahseder. Bu sınıflamada önceki sınıflamalarla benzer şekilde değerlendirme becerisine ilişkin açıklamalar yapılmıştır. Ancak sunulan bilgilerin alanyazından hareketle değerlendirilmesi ve konuşmadaki kanıt ifadelerini, sunulan kaynakları inceleme yönüyle bu sinıflama diğerlerinden ayrılmaktadır.

Yalçın (2006) konuşmacının uzmanlık alanını değerlendirme, sunulan bilgilerin güncelliğini inceleme, konuşmanın kapsamı ile elde edilen sonucu karşılaştırma, dinlenilenleri önceki bilgilerle karşılaştırma, konuşmacının amacını inceleme becerilerini eleştirel dinleme kapsamında değerlendirirken Akyol (2006) konuşmada aktarılan düşünceleri belirleme ve düzenleme, konuşmacıyı değerlendirme, konuşmadaki propaganda ifadelerini belirleme, anlatım öykülemeye dayalıysa hikâye karakterlerini ve olgularını değerlendirme olarak açıklamaktadır. Bu sınıflamalar dinlenen bilgilerin önceki bilgilerle karşılaştırması, karakterleri ve olguları değerlendirme yönleriyle önceki siniflamalardan ayrilmaktadır.

Eleştirel dinleme 2006 Türkçe Öğretim Programı'nda bir dinleme yöntem/tekniği olarak yer almaktadır ve öğrencilerin eleştirel dinleme kapsamında dinlerken konuşmacının amacını belirlemeleri, konuşmacının konuya ilişkin yeterli bilgi sahibi olup olmadığını belirlemeleri, konuşmada verilen bilgilerin güncelliğini ve geçerliliğini incelemeleri, konuya ilişkin bakış açılarını

\footnotetext{
\begin{tabular}{r|l} 
Adres & Address \\
RumeliDE Dil ve Edebiyat Araştırmaları Dergisi & RumeliDE Journal of Language and Literature Studies
\end{tabular} Osmanağa Mahallesi, Mürver Çiçeği Sokak, No:14/8 Osmanağa Mahallesi, Mürver Çiçeği Sokak, No:14/8 Kadıköy - İSTANBUL / TÜRKIYE 34714 Kadıköy - ISTANBUL / TURKEY 34714 e-posta: editor@rumelide.com e-mail: editor@rumelide.com, tel: +90 505 7958124, +90 2167730616 phone: +90 505 7958124, +90 2167730616
} 
gözden geçirmeleri, konuşmada bir problem durumu ele alınmışsa sunulan çözüm önerilerinin bilimselliğini inceleyerek farklı çözüm önerileri verilip verilmediğini tespit etmeleri beklenmektedir. Ayrıca programda eleştirel dinlemenin soru sorma becerisi olarak yer alması önemlidir. Eleştirel dinleme sürecinde kullanılması önerilen sorular incelendiğinde bu soruların eleştirel dinlemenin kapsamını özetleyecek nitelikte olduğu görülmektedir. Programda bahsedilen becerilerin çoğu önceki sinıflamalarda yer almıştır. Ancak konuya ilişkin sunulan çözüm önerilerini inceleme ve farklı çözüm önerileri sunulup sunulmadığını tespit etme becerilerinden daha önce söz edilmemiştir. Fakat bu becerilerin kullanılabilmesi için konuşmada bir problem durumunun ele alınmış olması gereklidir. 2006 Türkçe Öğretim Programı'ndan farklı olarak daha sonraki öğretim programlarında eleştirel dinleme yöntem/teknik olarak yer almasına rağmen içeriğine ve uygulamaya ilişkin açıklamalar yapılmamıştır.

Celepoğlu (2012) eleştirel dinlemede dinleyicinin konuşmacının yaklaşımına ve konuşmasına birlikte odaklanması gerektiğini açıklarken konuşma sırasında aktarılanların doğruluğuna, verilen bilgilerin tutarlılığına, konuşmacının sunumu aktarım şekline ve dinleyiciye yaklaşımına, konuşmayı etkili hâle getirmek için neler yaptığına dikkat etmek gerektiğinden bahsetmiştir. Bu sinıflamada eleştirel dinlemenin özellikle değerlendirme boyutuna odaklanıldığ görülmektedir. Doğan (2017) eleştirel dinlemeyle ilişkili becerileri metinde verilmek istenen mesajın amacını sorgulama, ikna edicilik söylemlerini fark etme, aldatıcı dil kullanımını fark etme, propagandayı tanıma olarak ifade etmektedir. $\mathrm{Bu}$ açıklamada metindeki yönlendirmeleri anlama ve belirleme üzerinde durulduğu görülmektedir. Çarkıt (2018) araştırmasında eleştirel dinleme becerisinin boyutlarını eleştirel anlamlandırma, analiz/çözümleme, sorgulama, karşlaştırma ve değerlendirme olarak ifade etmiştir. Eleştirel anlamlandırma boyutu not alma, soru sorma, konu-ana fikir- yardımcı fikir belirleme becerilerini; analiz/çözümleme boyutu karakter analizi yapma, öznel/nesnel anlatımı belirleme, ikna ve propaganda unsurlarını belirleme, mecaz ve mizah unsurlarını belirleme becerilerini içermektedir. Sorgulama boyutu öğrencilerin soru sormayı öğrenmelerini, metnin yazılış amacını belirlemelerini, dil ve anlatım özelliklerini inceleyebilmelerini, metne yönelik kendi görüşlerini ifade edebilmelerini; karşılaştırma boyutu öğrencilerin metnin inandırıcılığını, tutarlılığını, metindeki neden sonuç ilişkilerini inceleyebilmelerini, metinlerdeki benzer ve farklı yönleri belirleyebilmelerini; değerlendirme boyutu öğrencilerin metne yönelik eleştirel değerlendirme yapabilmelerini kapsamaktadır. Yapılan bu sınıflamanın eleştirel dinlemenin pek çok boyutunu kapsadığı ve bu boyutların üç temel basamakta toplandığı görülmektedir.

Alanyazın incelendiğinde eleştirel dinlemeye ilişkin sınıflamalarda farklı becerilerin ele alındığı görülmektedir. Bu araştırmalardan hareketle eleştirel dinlemenin farklı becerileri kapsayan karmaşı bir bütün olduğunu söylemek mümkündür. Ayrıca alanyazında ortak bir sınıflamanın bulunmaması yapılacak çalışmalarda ve öğretim sürecinde eksikliklere neden olmaktadır. Bu nedenle bu araştırmanın amacı eleştirel dinleme becerisinin kapsamını alanyazından hareketle incelemek ve yeni bir sinfflama ortaya koymak olarak belirlenmiştir.

\section{Yöntem}

\section{Araştırmanın modeli}

Araştırmada betimsel tarama yöntemi kullanılmıştır. Betimsel araştırmalar, bir durumu tanımlamaya yöneliktir. Eğitim alanında yapılabilecek betimsel çalışmalar çeşitli grupların başarılarını belirlemek, öğretmenlerin, yöneticilerin ya da danışmanların davranışlarını tanımlamak, ebeveynlerin tutumlarını

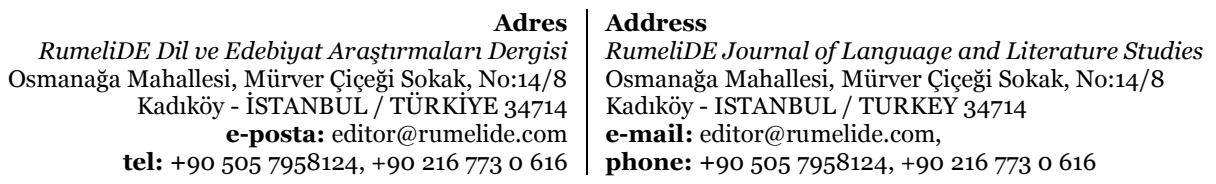


ve okulun fiziki şartlarını tanımlamak olabilir. Olgunun tanımlanması tüm araştırma gayretlerinin başlangıç noktasıdır (Büyüköztürk, Çakmak, Akgün, Karadeniz ve Demirel, 2014: 22).

\section{Verilerin toplanması ve analizi}

Eleştirel dinlemenin farklı bileşenlerden oluşan bir bütün olması ve alanda kabul görmüş bir sınıflamanın bulunmaması sebebiyle alanyazındaki bilgilerden hareketle eleştirel dinlemenin kapsamına yönelik yeni bir sınıflama oluşturulmuş̧tur. Bu sınıflama hazırlanırken ilk olarak araştırmacı tarafından alanyazında ulaşılan sınıflamalar incelenmiştir. Sinıflamaların maddeleri incelenerek ortak olanlar bir boyut altında toplanmıştır. İnceleme yapılırken bazı maddelerin birden fazla boyutta yer alabileceği görüldüğünden bu maddeler birden fazla boyuta yerleştirilmiştir. Sinıflama ilk olarak araştırmacılar tarafından yapılmıştır. İkinci basamakta üç Türkçe eğitimi alan uzmanından görüşler alınarak sınıflama yeniden şekillendirilmiştir.

\section{Bulgular}

Eleştirel dinleme kapsamındaki becerilerden ilki öznel ve nesnel anlatımı belirlemektir. Beceriye ilişkin detaylar Tablo 1'de gösterilmiştir.

Tablo 1. Öznel ve nesnel anlatımı belirleme boyutunu içeren sınıflamalar

\begin{tabular}{ll}
\hline Beceri & Araştırma bilgisi \\
\hline Gerçek ile görüş farkını tanıma & Early, 1954 \\
Gerçek ile görüş farkını tanıma & Devine, 1961 \\
Gerçek ve görüş farkını belirlemek için dinleme & Laurent, 1963 \\
Gerçek ile görüş farkını ayırt edebilme & Groom, 1970 \\
Kullanılan ifadelerin öznellik/nesnelliğini değerlendirme & Richards, 1977 \\
Dilin öznelliğini/nesnelliğini belirleyebilme & Davis-Rice, 1982 \\
Görüş ile gerçek arasındaki farkı belirleyebilme & Davis-Rice, 1982 \\
Konuya ilişkin bakış açılarını belirleme & Türkçe Öğr.Pr., 2006 \\
Fikirleri belirleme & Akyol, 2006 \\
Analiz/çözümleme & Çarkıt, 2018 \\
\hline
\end{tabular}

Öznel ve nesnel anlatımı belirleme boyutuna incelenen araştırmalar içerisinde 9 farklı araştırmada yer verildiği tespit edilmiştir. Öznel ifadelerin kullanıldığı anlatımlarda yönlendirmelere, yanlı ifadelere ve duygu bildiren ifadelere daha sık rastlanmaktadır. Bu nedenle eleştirel dinleme yapabilen kişi dinlediklerinde kullanılan ifadelere dikkat ederek bu ifadelerin öznelliğini/nesnelliğini sorgulamalıdır.

Eleştirel dinleme kapsamında yer alan becerilerden anlatımın taraflı olup olmadığını belirleme boyutuna ilişkin bilgiler Tablo 2'de gösterilmiştir.

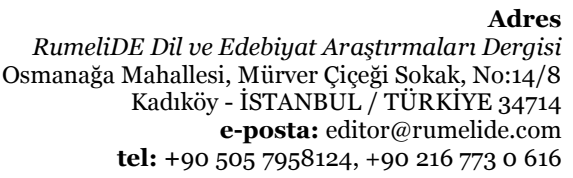

Adres

RumeliDE Journal of Language and Literature Studies Osmanağa Mahallesi, Mürver Çiçeği Sokak, No:14/8

Kadıköy - ISTANBUL / TURKEY 34714

e-mail: editor@rumelide.com,

phone: +90 505 7958124, +90 2167730616 
Tablo 2. Anlatımın taraflı olup olmadı̆̆ını belirleme boyutunu içeren sınıflamalar

\begin{tabular}{ll}
\hline Beceri & Araştırma bilgisi \\
\hline Konuşmacının yanlı olup olmadı̆̆ını belirleme & Beery, 1946 \\
Duygu ifadelerine dikkat etme & Beery, 1946 \\
Resmi dil ile duygusal dil farkını tanıma & Early, 1954 \\
Yanlılığı ve önyargıyı tanıma & Early, 1954 \\
Kullanılan dildeki duygu ifadeleri/nesnel ifadeleri tanıma & Devine, 1961 \\
Metindeki duygusal ifadeleri belirlemek için dinleme & Laurent, 1963 \\
Duygusal olan dil kullanımı ile nesnel dil kullanımını ayırt edebilme & Groom, 1970 \\
Kullanılan dilin yanlı olup olmadı̆̆ını değerlendirme & Richards, 1977 \\
Konuşmacının bilgiyi sunuş biçimine ve dinleyiciye yönelik tutumuna dikkat etme & Celepoğlu, 2012 \\
Konuşmayı etkin kılmak için yapılanları inceleme & Celepoğlu, 2012 \\
Konuya ilişkin bakış açılarını belirleme & Türkçe Öğr.Pr., 2006 \\
\hline
\end{tabular}

Anlatımın taraflı olup olmadığını belirleme boyutuna incelenen araştırmalar içerisinde 8 farklı araştırmada yer verildiği tespit edilmiştir. Anlatımının taraflı olup olmadığını belirleme becerisi bireyin dinlediklerindeki yönlendirmeleri fark etmesi anlamına geldiğinden eleştirel dinleme kapsamında bireylerin kazanması gereken bir beceridir.

Eleştirel dinleme kapsamında yer alan becerilerden metnin konusunu ve ana fikrini belirleme boyutuna ilişkin bilgiler Tablo 3'te gösterilmiştir.

Tablo 3. Metnin konusunu ve ana fikrini belirleme boyutunu içeren sınıflamalar

\begin{tabular}{ll}
\hline Beceri & Araştırma bilgisi \\
\hline Konuşmacının amacını kavrama & Devine, 1961 \\
Konuyu anlamak için dinleme & Laurent, 1963 \\
Konuşmacının amacını belirleme & Lundsteen, 1963 \\
Konuşmacının amacını belirleyebilme ve pazarlama tekniklerini anlama & Groom, 1970 \\
Ana fikri ve temel konuları belirleme & Richards, 1977 \\
Konuşmacının amacını belirleyebilme & Davis- Rice, 1982 \\
Konuşmacının amacını belirleme & Türkçe Öğr.Pr., 2006 \\
Konuşmanın yapılma amacını ve konuşma ortamını inceleme & Yalçın, 2006 \\
Fikirleri, yargıları ve tercihleri düzenleme & Akyol, 2006 \\
Konuşmacının aktardıklarını anlama & Celepoğlu, 2012 \\
Metnin amacını sorgulama & Doğan, 2017 \\
Eleştirel anlamlandırma & Çarkıt, 2018 \\
Sorgulama, karşılaştırma ve değerlendirme & Çarkıt, 2018 \\
\hline
\end{tabular}

Metnin konusunu ve ana fikrini belirleme boyutuna incelenen araştırmalar içerisinde 12 farklı araştırmada yer verildiği tespit edilmiştir. Eleştirel dinleyici konuşmacının gerçek amacını kavramalı ve konuşmanın konusunu tespit edebilme becerisine sahip olmalıdır.

Eleştirel dinleme kapsamında yer alan becerilerden propaganda ifadelerini tanıma boyutuna ilişkin bilgiler Tablo 4'te gösterilmiştir. 
Tablo 4. Propaganda ifadelerini tanıma boyutunu içeren sınıflamalar

\begin{tabular}{ll}
\hline Beceri & Araştırma bilgisi \\
\hline Propagandayı tanıma & Early, 1954 \\
Pazarlama tekniklerini tanıma & Early, 1954 \\
Konuşmacının yönlendirmelerini belirleyebilme & Devine, 1961 \\
Propagandayı değerlendirme ve analiz etme & Lundsteen, 1963 \\
Propaganda tekniklerini tanıma & Groom, 1970 \\
Konuşmacının amacını değerlendirme ve pazarlama tekniklerini anlama & Groom, 1970 \\
Metindeki yönlendirmeleri belirleme & Richards, 1977 \\
Propagandayı tespit etme & Akyol, 2006 \\
İkna edicilik barındıran ifadeleri ayırt etme & Doğan, 2017 \\
Aldatıcı dil kullanımını ayırt etme & Doğan, 2017 \\
Propaganda araçlarını bilme & Doğan, 2017 \\
Analiz/çözümleme & Çarkıt, 2018 \\
\hline
\end{tabular}

Propaganda ifadelerini tanıma boyutuna incelenen araştırmalar içerisinde 8 farklı araştırmada yer verildiği tespit edilmiştir. Konuşmadaki propaganda unsurlarının fark edilmesi, konuşmadaki bir fikre ya da ürüne yönlendiren ifadelerin belirlenebilmesi eleştirel dinleme ile ilişkili becerilerdir.

Eleştirel dinleme kapsamında yer alan becerilerden metnin konusunu değerlendirme ve sonuç çıkarma boyutuna ilişkin bilgiler Tablo 5 'te gösterilmiştir.

Tablo 5. Metnin konusunu değerlendirme ve sonuç çıkarma boyutunu içeren sınıflamalar

\begin{tabular}{ll}
\hline Beceri & Araştırma bilgisi \\
\hline Konuyu farklı bakış açılarıyla değerlendirebilme & Beery, 1946 \\
Konuşmacının savını değerlendirme & Early, 1954 \\
Çıkarımlar yapabilme ve değerlendirme & Early, 1954 \\
Sonuç çlkarmak için dinleme & Laurent, 1963 \\
Konunun değerlendirilmesi ve analiz edilmesi & Lundsteen, 1963 \\
Varsayımları ve sonuçları tanımlama & Richards, 1977 \\
Hikâye karakterlerini ve olguları değerlendirme & Akyol, 2006 \\
Performansı değerlendirme & Akyol, 2006 \\
Konuşmacının aktardığı fikirleri önceki bilgilerle karşılaştırma & Yalçın, 2006 \\
Sorgulama, karşılaştırma ve değerlendirme & Çarkıt, 2018 \\
\hline
\end{tabular}

Metnin konusunu değerlendirme ve sonuç çıarma boyutuna incelenen araştırmalar içerisinde 8 farklı araştırmada yer verildiği tespit edilmiştir. Konuşma sonrasında dinleyicinin dinleme sürecine ilişkin kendi fikirlerini sunması ve dinlediklerinden hareketle bir sonuca ulaşarak değerlendirmeler yapması eleştirel dinleme içerisinde yer alan becerilerdendir.

Eleştirel dinleme kapsamında yer alan becerilerden tutarlılığı değerlendirme boyutuna ilişkin bilgiler Tablo 6'da gösterilmiştir. 
Tablo 6. Tutarlılığı değerlendirme boyutunu içeren sınıflamalar

\begin{tabular}{ll}
\hline Beceri & Araştırma bilgisi \\
\hline Yanlış anlamaları sorularla kontrol edebilme & Early, 1954 \\
Metindeki tutarlılı̆̆ı değerlendirme & Richards, 1977 \\
Metindeki mantıksal hataları tanımlama & Richards, 1977 \\
Iffadelerden mantıksal bir sonuca ulaşılıyor mu? & Davis- Rice, 1982 \\
Konuşmacının söylemleri ile sonucun bağlantılı olup olmadığını inceleme & Yalçı, 2006 \\
Verilen bilgilerin tutarlılığını inceleme & Celepoğlu, 2012 \\
Sorgulama, karşıllaştırma ve değerlendirme & Çarkıt, 2018 \\
\hline
\end{tabular}

Tutarlılığı değerlendirme boyutuna incelenen araştırmalar içerisinde 6 farklı araştırmada yer verildiği tespit edilmiştir. Dinleme sürecinde etkili bir dinleme yaparak metindeki mantık hatalarını, tutarsız ifadeleri tespit etmek eleştirel dinleme sürecinde yer alan becerilerden birisidir.

Eleştirel dinleme kapsamında yer alan becerilerden metindeki kanıt ifadelerini ve konuşmacıyı değerlendirme boyutuna ilişkin bilgiler Tablo 7'de gösterilmiştir.

Tablo 7. Metindeki kanıt ifadelerini ve konuşmacıyı değerlendirme boyutunu içeren sınıflamalar

\begin{tabular}{ll}
\hline Beceri & Araştırma bilgisi \\
\hline Bilginin kaynağını sorgulama & Beery, 1946 \\
İfadeler için kanıt talep etme & Beery, 1946 \\
Konuşmacının konudaki yeterliğini inceleme & Devine, 1961 \\
Çıkarımlar yapabilme ve verilen materyali sorgulama & Groom, 1970 \\
Konuya ilişkin bilgi edinene kadar değerlendirilmenin ertelenmesi & Davis- Rice, 1982 \\
İlgili bilgilerin alanyazın ışı̆̆ında değerlendirilmesi & Davis- Rice, 1982 \\
Konuya ilişkin kanıtların değerlendirilmesi & Davis- Rice, 1982 \\
Metnin temel dayanaklarını belirleyebilme & Davis- Rice, 1982 \\
Konuşmacı konuya ilişkin yeterliliğini değerlendirme & Türkçe Öğr.Pr., 2006 \\
Sunulan bilgilerin güncelliğini ve geçerliliğini değerlendirme & Türkçe Öğr.Pr., 2006 \\
Çözüm önerilerinin bilimselliğini değerlendirme & Türkçe Öğr.Pr., 2006 \\
Alternatif çözüm önerileri olup olmadı̆̆ını belirleme & Türkçe Öğr.Pr., 2006 \\
Fikirleri, yargıları ve tercihleri düzenleme & Akyol, 2006 \\
Araştırmacının uzmanlık alanını değerlendirme & Yalçın, 2006 \\
Sunulan bilgilerin tarihini inceleme & Yalçın, 2006 \\
Aktarılanların doğruluğunu inceleme & Celepoğlu, 2012 \\
\hline
\end{tabular}

Metindeki kanıt ifadelerini ve konuşmacıyı değerlendirme boyutuna incelenen araştırmalar içerisinde 8 farklı araştırmada yer verildiği tespit edilmiştir. Konuşma sürecinde konuşmacının söylemlerine ilişkin kanıtlar sunması, metinde verilen amacın belirli gerekçelere dayandırılması bir metnin inandırıcılığını arttıran unsurlardır. Bu nedenle, eleştirel dinleme yapabilen etkili bir dinleyici metinde aktarılanlara ilişkin kanıt olup olmadığı incelemeli, kanıtlarının geçerliliği hakkında düşünerek konuşmacının konuya hâkimiyetini sorgulamalıdır.

\section{Sonuç}

Araştırma sonucunda eleştirel dinlemenin öznel ve nesnel anlatımı belirleme, anlatımın taraflı olup olmadığını belirleme, metnin konusunu ve ana fikrini belirleme, propaganda ifadelerini tanıma,

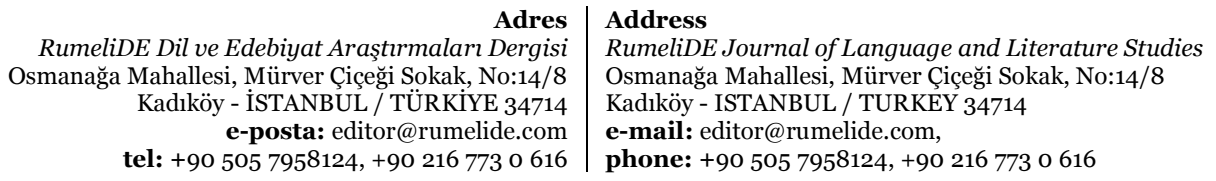


metnin konusunu değerlendirme ve sonuç çıkarma, tutarlılığı değerlendirme, metindeki kanıt ifadelerini ve konuşmacıyı değerlendirme becerilerini kapsadı̆̆ı tespit edilmiştir.

Öznel ve nesnel anlatımı belirleme becerisine 9 (Akyol, 2006; Çarkıt, 2018; Davis-Rice, 1982; Devine, 1961; Early, 1954; Groom, 1970; Laurent, 1963; Richards, 1977; Türkçe Öğr.Pr., 2006), anlatımın taraflı olup olmadığını belirleme becerisine 8 (Beery, 1946; Celepoğlu, 2012; Devine, 1961; Early, 1954; Groom, 1970; Laurent, 1963; Richards, 1977; Türkçe Öğr.Pr., 2006), metnin konusunu ve ana fikrini belirleme becerisine 12 (Akyol, 2006; Celepoğlu, 2012; Çarkıt, 2018; Davis-Rice, 1982; Devine, 1961; Doğan, 2017; Groom, 1970; Laurent, 1963; Lundsteen, 1963; Richards, 1977; Türkçe Öğr.Pr., 2006; Yalçın, 2006), propaganda ifadelerini tanıma becerisine 8 (Akyol, 2006; Çarkıt, 2018; Devine, 1961; Doğan, 2017; Early, 1954; Groom, 1970; Lundsteen, 1963; Richards, 1977), metnin konusunu değerlendirme ve sonuç çıkarma becerisine 8 (Akyol, 2006; Beery, 1946; Çarkıt, 2018; Early, 1954; Laurent, 1963; Lundsteen, 1963; Richards, 1977; Yalçın, 2006), tutarlılı̆̆ değerlendirme becerisine 6 (Celepoğlu, 2012; Çarkıt, 2018; Davis-Rice, 1982; Early, 1954; Richards, 1977; Yalçın, 2006), metindeki kanıt ifadelerini ve konuşmacıyı değerlendirme becerisine 8 (Akyol, 2006; Beery, 1946; Celepoğlu, 2012; Davis-Rice, 1982; Devine, 1961; Groom, 1970; Türkçe Öğr.Pr., 2006; Yalçın, 2006) araştırmada yer verilmiştir. İncelenen araştırmalarda en sık yer verilen becerinin metnin konusunu ve ana fikrini belirleme becerisi, en az yer verilen becerinin ise tutarlılığı değerlendirme becerisi olduğu görülmektedir. Araştırmalarda metnin konusunu ve ana fikrini belirleme, metnin konusunu değerlendirme ve sonuç çlkarma, metindeki kanıt ifadelerini ve konuşmacıyı değerlendirme becerileri birlikte ele alındığından bu araştırmada birlikte sınıflandırılmıştır. Ancak bu becerilerin kendi içerisinde birden fazla beceriyi kapsadığı göz önünde bulundurulmalıdır.

Eleştirel dinleme becerisine yönelik araştırmalar yabancı alanyazında 1940'lı yllarda dönemin özelliklerinden dolayı ortaya çımıştır. Ancak Türkiye'de alanyazında bu konunun ele alınması daha geç tarihlere dayanmaktadır. Bu nedenle öncelikle dinleme ve eleştirel dinleme konularında yapılacak yeni araştırmalar alanyazına katkıda bulunacaktır. Ayrıca bu araştırmada belirli çalışmaların sonuçları sentezlenerek yeni bir sınıflama ortaya konulmuştur. Eleştirel dinleme becerisinin kapsamına yönelik alanyazında kabul görmüss bir sınıflama olmamasından dolayı bu konuda yapılacak uygulamaya dönük farklı araştırmalar alana katkı sağlayacaktır.

\section{Kaynakça}

Akyol, H. (2006). Yeni programa uygun Türkçe öğretim yöntemleri. Ankara: Kök.

Beery, A. (1946). Listening activities in the elementary school. The Elementary English Review, 69-79.

Brewster, L. W. (1956). An explonatory study of some aspects of critical listening among college freshmen (Doktora Tezi). ProQuest Dissertations and Theses veri tabanından erişildi. (UMI No. o017461)

Büyüköztürk, Ş., Kılıç Çakmak, E., Akgün, Ö. E., Karadeniz, Ş. ve Demirel, F. (2014). Bilimsel araştırma yöntemleri. Ankara: Pegem A.

Celepoğlu, A. (2012). Dinleme. L. Beyreli (Ed.), Yazılı ve Sözlü Anlatım (ss. 184-190). Ankara: Pegem A.

Çarkıt, C. (2018). Ortaokul Türkçe derslerinde eleştirel dinleme/izleme uygulamalar üzerine bir eylem araştırması (Doktora Tezi). YÖK Tez Merkezi veri tabanından erişildi (Tez No: 524021).

Davis-Rice, H. J. (1982). Critical listening abilities of college students ıdentified as superior, average, or poor readers (Doktora Tezi). ProQuest Dissertations and Theses veri tabanından erişildi. (UMI No. 8310235)

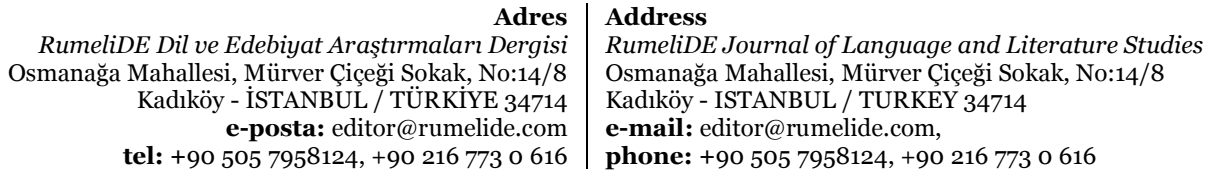

tel: +90 505 7958124, +90 216773 o 616 
Devine, T. (1961). The development and evaluation of a series of recordings for teaching certain critical listening abilities (Doktora Tezi). ProQuest Dissertations and Theses veri tabanından erişildi. (UMI No. 6106569)

Doğan, B. (2017). Strateji temelli dinleme etkinliklerinin yedinci sinıf öğrencilerinin dinleme becerisiyle strateji kullanma düzeyine etkisi (Yayımlanmamış doktora tezi). İnönü Üniversitesi Eğitim Bilimleri Enstitüsü, Malatya.

Groom, B. H. (1970). An experimental study designed to develop selected informative listening skills of fifth and sixth grade students (Doktora Tezi). ProQuest Dissertations and Theses veri tabanından erişildi. (UMI No. 7103639)

Güneş, F. (2013). Türkçe öğretimi yaklaşımlar ve modeller. Ankara: Pegem A.

Imhof, M. (2008). What have you listened to in school today?. The International Journal of Listening, 22(1), 1-12. doi: 10.1080/10904010701802121

Laurent, M. J. (1963). The construction and evaluation of a listening curriculum for grades 5 and 6 (Doktora Tezi). ProQuest Dissertations and Theses veri tabanından erişildi. (UMI No. 6407179)

Lundsteen, S. (1963). Teaching abilities in critical listening in fifth and sixth grade pupils (Yayımlanmamış doktora tezi). California Üniversitesi, Berkeley.

Lundsteen, S. (1971). Listening: Its impact on reading and the other language arts. Illinois, USA: Urbana.

Mersand, J. (1951). Why teach listening?. The English Journal, 4O(5), 260-265.

Milli Eğitim Bakanlığı. (2006). Türkçe dersi öğretim programı. Ankara: Milli Eğitim Bakanlığı.

Pinnell, G. S. ve Jagger, A. M. (2003). Oral language: speaking and listening in elementary classrooms. Flood ve diğerleri (Ed.), Handbook Of Research On Teaching The English Language Arts (ss. 881-913). NJ: Erlbau.

Rankin, P. (1928). The Importance of listening ability. The English Journal, 17(8), 623-630.

Richards, R. A. (1977). The development and evaluation of a test of critical listening for use with college freshmen and sophomores (Doktora Tezi). ProQuest Dissertations and Theses veri tabanından erişildi. (UMI No. 7716443)

Robertson, A. K. (2002). Etkili dinleme. (Çev. E.S. Yarmalı). İstanbul: Hayat.

Trace, J. (2013). Designing a task-based critical listening construct for listening assessment. Second Language Studies, 32(1), 59-111.

Wolvin, A. D. ve Coakley, C. G. (2000) Listening education in the 21st century. International Journal of Listening, 14(1), 143-152. doi: 10.1080/10904018.2000.10499040

Yalçın, A. (2006). Türkçe öğretim yöntemleri: Yeni yaklaşımlar. Ankara: Akçağ.

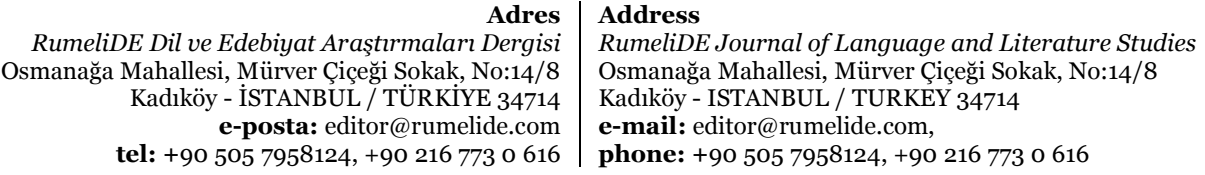

